\title{
Analisis Daerah Rawan Bencana Tsunami Terhadap Pemanfaatan Lahan Perumahan dan Permukiman Kota Gunungsitoli Berbasis Geospasial
}

\author{
Jurnalisman Harefa $^{1^{*}}$, Zulkifli Nasution ${ }^{2}$, Achmad Siddik Thoha ${ }^{3}$ \\ ${ }^{1}$ Perencanaan Wilayah Pedesaan, Sekolah PascaSarjana, Universitas Sumatera Utara \\ ${ }^{2}$ Fakultas Pertanian, Universitas Sumatera Utara \\ ${ }^{3}$ Fakultas Kehutanan, Universitas Sumatera Utara \\ *Koresponden email: joeharefa@gmail.com
}

Diterima: 9 Desember 2019

Disetujui: 11 Desember 2019

\begin{abstract}
Land-use pattern of Gunungsitoli municipality cannot be controlled yet, where land originally designated for the Local Protection Zone or the coastal green zone has been converted to function as built-up land for housing and settlement activities. Spatial Planning Law Number 26/2007, Regional Regulation No. 12/2012, and Presidential Regulation Number 51/2016 in Article (1) has regulated spatial layout and coastline. Research type used in this research is descriptive research with a qualitative-quantitative approach. This study aims to predict population growth in 2020-2039, land changes in 2010-2019 and distribution of tsunami prone areas analysis. The results of this study predict population growth in Gunungsitoli municipality for the next 20 years, 2020-2039, to 148.341 people. The biggest land use change / change analysis occurred in Gunungsitoli sub-district with a percentage of $25,38 \%$ of the total area of change in all Gunungsitoli sub-districts, and the smallest land use change's percentage that occurred in Gunungsitoli West sub-district because this sub-district has a sloping and bumpy topography. The results of the tsunami disaster area analysis showed Gunungsitoli sub-district is the most extensive vulnerability impacted of 3.449 hectares. Subsequently followed by Gunungsitoli Idanoi sub-district, South Gunungsitoli sub-district and North Gunungsitoli sub-district.
\end{abstract}

Keywords: Natural Disasters, Land Use, Gunungsitoli City, Geospatial, Union / Overlay method

\begin{abstract}
Abstrak
Pola Pemanfaatan lahan Kota Gunungsitoli belum dapat dikendalikan, dimana lahan sedianya untuk zona Kawasan Perlindungan Setempat atau zona hijau pesisir dialih fungsikan sebagai lahan terbangun untuk kegiatan perumahan dan permukiman penduduk. Undang-Undang Penataan Ruang Nomor 26 Tahun 2007 Perda no 12/2012, dan Peraturan Presiden Nomor 51 Tahun 2016 pada pasal (1) telah mengatur tentang tata ruang dan sempadan pantai. Jenis penelitian yang digunakan dalam penelitian ini adalah penelitian deskriptif dengan pendekatan kualitatif-kuantitatif. Penelitian ini bertujuan memprediksi pertumbuhan penduduk tahun 2020-2039, perubahan lahan tahun 2010-2019 dan analisis sebaran daerah rawan bencana tsunami. Hasil penelitian ini memprediksi pertumbuhan penduduk di Kota Gunungsitoli selama 20 tahun kedepan yaitu 2020-2039 adalah 148.341 jiwa. Analisis alih fungsi/perubahan lahan terbesar terjadi di kecamatan Gunungsitoli dengan persentase 25,38 \% dari total luas perubahan di seluruh kecamatan di Kota Gunungsitoli, dan persentase alih fungsi lahan yang terjadi terkecil di kecamatan Gunungsitoli Barat karena kecamatan ini memiliki topografi landai dan bergelombang. Hasil analisis daerah bencana tsunami memperlihatkan kecamatan Gunungsitoli merupakan salah satu kecamatan yang memiliki nilai kerentanan paling luas dengan besaran 3.449 Hektar. Selanjutnya diikuti oleh Kecamatan Gunungsitoli Idanoi, Kecamatan Gunungsitoli Selatan dan Kecamatan Gunungsitoli Utara .

Kata Kunci: Bencana Alam, Penggunaan Lahan, Kota Gunungsitoli, Geospasial, metode Union/Overlay
\end{abstract}

\section{Pendahuluan}

Pengendalian dan pengawasan perencanaan tata ruang di Kota Gunungsitoli telah menjadi Peraturan Daerah (Perda) Nomor 12 Tahun 2012 [1]. Perumusannya sebagaimana diamanatkan dalam Undang-undang Penataan Ruang Nomor 26 Tahun 2007 menjelaskan fungsi setiap kawasan baik itu kawasan lindung dan kawasan budidaya. Terkhusus pada kawasan lindung untuk kawasan perlindungan setempat dijelaskan bahwa perlu ditetapkan zona perlindungan setempat pada daerah-daerah rawan 
bencana tsunami. Akan tetapi hal tersebut tidak sesuai dengan kondisi di Kota tersebut, daerah pinggiran pantai difungsikan sebagai kawasan terbangun [2]. Tujuan penelitian ini adalah mengetahui proyeksi pertumbuhan pendududuk Kota Gunungsitoli tahun 2020-2039, perubahan penggunaan lahan Kota Gunung Sitoli saat setelah pasca bencana tsunami dan gempa tahun 2015 dan tahun 2018 serta mengindentifikasi distribusi zona-zona kawasan rawan bencana tsunami di Kota Gunung Sitoli yang berbasis geospasial.

\section{Tinjauan Pustaka}

\section{Peraturan Daerah (Perda) Nomor 12 Tahun 2012}

Pengendalian dan pengawasan perencanaan tata ruang di Kota Gunungsitoli telah menjadi Peraturan Daerah (Perda) Nomor 12 Tahun 2012, pada arahan rencana pola ruang Kota Gunungsitoli menyebutkan bahwa Pesisir Pantai Kota Gunungsitoli sebagai zona perlindungan setempat atau zona hijau. Pada kenyataannya pada zona hijau tersebut beralih fungsi menjadi kawasan permukiman dan perumahan atau lahan terbangun.

\section{Undang- Undang Penataan Ruang Nomor 26 Tahun 2007}

Dalam Undang- Undang Penataan Ruang Nomor 26 Tahun 2007, zona perlindungan setempat yang sering disebut dengan zona lindung berfungsi sebagai zona hijau untuk mengurangi resiko bencana khususnya untuk bencana tsunami pada daerah pesisir pantai. Penetapan Zona Sempadan Pantai juga diamanatkan dalam Peraturan Presiden Nomor 51 Tahun 2016 pada pasal (1) menyebutkan sempadan pantai ditetapkan minimal 100 (seratus) meter dari titik pasang tertinggi ke arah darat dan juga dalam pasal (9) Zona Sempadan pantai berfungsi sebagai zona untuk mengurangi ancaman gempa, tsunami, erosi atau abrasi, badai dan banjir dari laut.

\section{Metode Penelitian}

\section{Lokasi Penelitian}

Lokasi Penelitian adalah Kota Gunungsitoli yang memiliki luas wilayah mencapai $\pm 469.36 \mathrm{~km}^{2}$ atau mencapai $0.63 \%$ dari luas wilayah Provinsi Sumatera Utara. Tabel 1 memperlihatkan daftar kecamatan di wilayah administrasi Kota Gunungsitoli yang terdiri dari enam kecamatan yang terdiri dari Kecamatan Gunungsitoli, Kecamatan Gunungsitoli Alo'oa, Kecamatan Gunungsitoli Barat, Kecamatan Gunungsitoli Idanoi, Kecamatan Gunungsitoli Utara, Kecamatan Gunungsitoli Selatan. Gambar 1 menunjukkan peta lokasi penelitian yaitu di Kota Gunungsitoli [3].
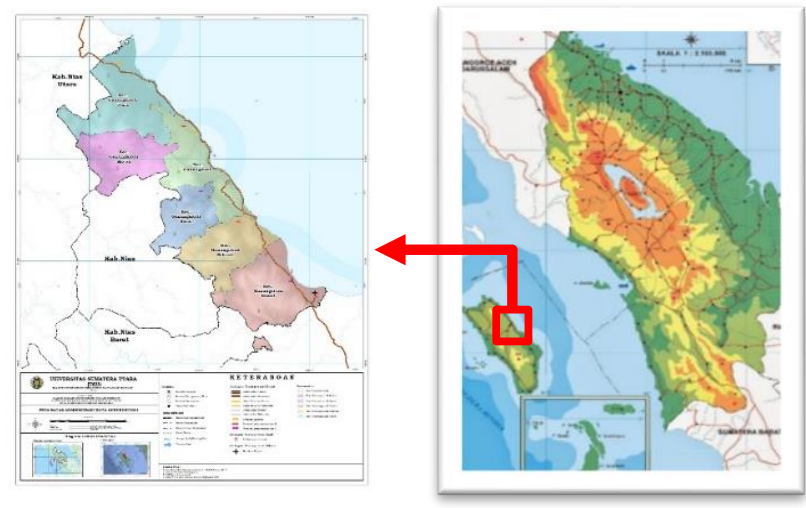

Gambar 1. Peta lokasi penelitian Sumber: BPS Kota Gunungsitoli (2019)

Tabel 1. Kecamatan di Kota Gunungsitoli

\begin{tabular}{cccc}
\hline No & Kecamatan & Luas $\left(\mathrm{Km}^{2}\right)$ & Persentase Luas (\%) \\
\hline 1. & Gunungsitoli Idanoi & 134,78 & 28,72 \\
2. & Gunungsitoli Selatan & 56,85 & 12,11 \\
3. & Gunungsitoli Barat & 28,70 & 6,11 \\
4. & Gunungsitoli & 109,09 & 23,24 \\
5. & Gunungsitoli Alo'oa & 60,21 & 12,83 \\
6. & Gunungsitoli Utara & 79,73 & 16,99 \\
\hline & Jumlah & 469.36 & 100,00 \\
\hline
\end{tabular}

Sumber: BPS Kota Gunungsitoli (2019) 


\section{Peralatan Penelitian}

Peralatan penelitian ini adalah laptop dengan perangkat lunak Windows 10, Microsoft Excel, Microsoft Word dan Google Chrome sebagai peramban situs internet.

\section{Jenis Penelitian dan Sumber Data}

Jenis penelitian yang digunakan dalam penelitian ini adalah penelitian deskriptif dengan pendekatan kualitatif-kuantitatif. Penelitian deskriptif yaitu proses penelitian yang lebih mengarah pada pengungkapan masalah atau keadaan sebagaimana fakta yang ada [4].

Penelitian deskripif dengan pendekatan kualitatif digunakan untuk memproyeksi pertumbuhan penduduk dan aspek yang mempengaruhinya. Analisis kependudukan juga diukur dengan tingkat/rate. Tingkat/rate adalah ukuran frekuensi suatu penyakit atau peristiwa/kejadian tertentu yang terjadi pada suatu populasi selama periode waktu tertentu, dibandingkan dengan jumlah penduduk yang menanggung resiko tersebut [5]

Pendekatan kuantitatif digunakan untuk melihat perubahan lahan pada tahun 2010-2019 dan analisis daerah rawan bencana tsunami terhadap arahan pemanfaatan lahan perumahan dan permukiman di Kota Gunungsitoli. Analisis perubahan lahan dan analisis daerah rawan bencana tsunami akan menggunakan analisis berbasis geospasial [6]. Dalam proses pengumpulan data penelitian, dibagi menjadi dua bagian pengumpulan data yaitu data sekunder dan data primer yang dilaksanakan pada Kawasan studi. Data sekunder merupakan data atau informasi yang diperoleh baik dari pihak instansi pemerintah ataupun swasta, sedangkan [7] data primer adalah data atau informasi yang diperoleh dari hasil observasi lapangan [8].

\section{Metode Analisis Data}

\section{Analisis Data dengan Metode Deskriptif-Evaluatif}

Teknik analisis yang digunakan dalam penelitian ini adalah metode deskriptif dengan menggunakan pendekatan kualitatif. Hasil penelitian difokuskan untuk memberi gambaran yang jelas tentang keadaan objek yang sedang diteliti. Dimana alat analisis yang digunakan dalam penelitian ini adalah analisis deskriptif-evaluatif (The descriptive-evaluation)[9]. Pada analisis ini diperlukan berbagai sumber data yang berbeda dan teori beserta kebijakan pemerintah untuk memberikan hasil yang optimalkan dalam penelitian ini.

\section{Analisis Proyeksi Penduduk}

Proyeksi penduduk merupakan bagian dari analisis yang digunakan dalam penelitian ini, tujuannya dari analisis proyeksi penduduk adalah untuk mendapatkan perkembangan penduduk selama 20 Tahun ke depan dengan menggunakan data lima tahun ke belakang atau data time series. Dengan proyeksi ini akan memberikan gambaran akan pertumbuhan dan perkembangan penduduk di Kota Gunungsitoli yang terdiri dari enam kecamatan administrasi [10].

\section{Analisis Matriks Persandingan Perubahan Penggunaan Lahan berbasis Geospasial}

Analisis perubahan penggunaan lahan lahan dengan metode matriks persandingan pada daerah penelitian dilakukan untuk mendapatkan gambaran tentang dinamika perubahan penggunaan lahan pada saat setelah pasca tsunami dengan kondisi saat ini. Data informasi penggunaan lahan pada saat pasca tsunami, didapatkan dari hasil pengolahan dengan menggunakan perangkat lunak ArcGIS 10.5. Hasil pengolahan dari perangkat lunak ArcGIS akan memunculkan informasi persentase luasan dan klasifikasi penutupan lahan di Kota Gunungsitoli [11].

\section{Analisis Overlay dengan Metode Unions (Sumperimpose)}

Analisis spasial ini dilakukan untuk mengetahui sebaran luas dan kuantitas unit aspek yang diteliti secara spasial yang di teliti. Dalam melakukan analisis ini dilakukan dengan menggunakan Sistem Informasi Geografis (SIG)[12]. Metode pendekatan pada tahap kajian ini dilakukan dengan pembahasan menggunakan analisis deskriptif guna menerangkan data- data yang hasil dari analisis. Analisis spasial yang dilakukan menggunakan Software ArcMap 10 dengan geoprosessing tools (Overlay - Union) digunakan untuk mengetahui daerah-daerah permukiman yang masuk kedalam zona Kawasan bencana Tsunami serta presentasi jumlah bangunan yang berada pada kawasan rawan bencana Tsunami [13].

\section{Analisis Keputusan Multikriteria dengan Metode Simple Additive Weighting}

Analisis Kawasan Rawan Bencana Tsunami terhadap pengembangan kawasan perumahan dan permukiman di Kota Gunungsitoli dilakukan dengan menggunakan analisis keputusan multikriteria. Pada analisis multikriteria seringkali objek yang satu berbenturan dengan objek yang lainnya (seperti satu objek memperbaiki dan objek yang lain mungkin memperburuk). Analisis dimensional dapat membantu para pembuat keputusan agar dapat mengambil keputusan yang lebih baik pada kondisi tersebut. Analisis keputusan multikriteria spasial dapat dipikirkan sebagai proses yang menggabungkan dan 
mentransformasikan data input spasial dan aspasial kedalam keputusan resultan (output). Hukum keputusan multikriteria didefinisikan sebagai hubungan antara peta masukan dan keluaran [14]. Metode yang dipakai dalam analisis keputusan multikriteria adalah metode Simple Additive Weight (SAW), metoda ini berdasarkan konsep pembobotan rata-rata. Pembuat keputusan secara langsung menentukan bobot "kepentingan relatif" pada masing-masing peta tematik. Total nilai masing-masing alternatif didapatkan dengan mengalikan bobot yang ditentukan untuk masing-masing atribut dan menjumlahkan hasil atribut-atribut tersebut. Saat skor keseluruhan semua alternatif dihitung, alternatif dengan nilai tertinggi akan dipilih [15]

\section{Analisis Penentuan Daerah Rawan Bencana Tsunami berbasis Geospasial}

Penentuan daerah kerawanan bencana tsunami dilakukan dengan metode tumpang susun (overlay method) dan permodelan data. Overlay method dilakukan dengan menggabungkan data grafis parameterparameter yang mempengaruhi tsunami untuk menghasilkan daerah rawan tsunami [16] [17].

\section{Hasil dan Pembahasan \\ Pertumbuhan Penduduk}

Tabel 2 menampilkan hasil proyeksi penduduk dengan menggunakan metode geometri dengan model pertumbuhan exponensial (bunga berganda), maka jumlah penduduk di Kota Gunungsitoli selama 20 tahun kedepan dari tahun 2020 sampai tahun 2039 adalah 142.799 jiwa dan 148.341 jiwa. Pertumbuhan penduduk di Kota Gunungsitoli tidak terlalu signifikan jika disandingkan dengan faktorfaktor yang mempengaruhi pertumbuhan penduduk Kota Gunungsitoli dalam tahap pembangunan, disamping itu juga daya tampung industri untuk menyerap tenaga kerja masih belum ada.

Tabel 2. Pertumbuhan penduduk selama 20 tahun

\begin{tabular}{|c|c|c|c|c|c|c|}
\hline \multirow{2}{*}{ No } & \multirow{2}{*}{ Kecamatan } & \multicolumn{5}{|c|}{ Jumlah Penduduk (Jiwa) } \\
\hline & & 2020 & 2025 & 2030 & 2035 & 2039 \\
\hline 1. & Gunungsitoli Idanoi & 22.547 & 22.838 & 23.432 & 23.432 & 23.633 \\
\hline 2. & Gunungsitoli Selatan & 14.686 & 14.876 & 15.263 & 15.263 & 15.394 \\
\hline 3. & Gunungsitoli Barat & 7.828 & 7.929 & 8.136 & 8.136 & 8.206 \\
\hline 4. & Gunungsitoli & 71.182 & 72.102 & 73.977 & 73.977 & 74.613 \\
\hline 5. & Gunungsitoli Alo'oa & 7.054 & 7.145 & 7.331 & 7.331 & 7.394 \\
\hline 6. & Gunungsitoli Utara & 17.481 & 17.707 & 18.167 & 18.167 & 18.323 \\
\hline & Jumlah & 142.799 & 144.623 & 148.336 & 148.341 & 149.602 \\
\hline
\end{tabular}

Pertambahan penduduk pada dasarnya dipengaruhi oleh faktor - faktor demografi. Kelahiran dan kematian dinamakan faktor alami, sedangkan perpindahan penduduk dinamakan faktor non alami. Di dalam pengukuran demografi ketiga faktor tersebut diukur dengan tingkat/rate.

\section{Perubahan Penggunaan Lahan 2010 dan 2019}

Distribusi penggunaan lahan pada tahun 2019 di Kota Gunungsitoli cenderung pada penggunaan lahan yang bertipologi lahan tidak terbangun. Pada pola distribusi penggunaan lahannya, didominasi oleh penggunaan lahan pertanian lahan kering dengan luas 21.893,84 Hektar. Akan tetapi, pola sebaran penggunaan lahan permukiman di Kota Gunungsitoli terkonsentrasi di Kecamatan Gunungsitoli dipengaruhi kondisi topografi cenderung datar. Pemanfaatan lahan untuk kegiatan permukiman menjadi kendala Kota Gunungsitoli disebabkan keadaan topografi Kota Gunungsitoli yang datar hanya terdapat pada daerah kawasan pesisir pantai. Ini yang mengakibatkan pemanfaatan lahan untuk kawasan jalur hijau pantai atau sempadan pantai beralihfungsi menjadi kawasan terbangun dengan kegiatan yang campuran seperti rumah, perdagangan dan jasa, perhotelan dan lain sebagainya. Disamping itu jaringan jalan utama di Kota Gunungsitoli membentang pada daerah pesisir. Keadaan ini mempengaruhi bangkitan pembangunan akan secara otomatis mengikuti pola jaringan jalan terkhususnya pada jalan utama kota.

Tabel 3 memperlihatkan perubahan lahan terbangun dan tidak terbangun dan menjelaskan perkembangan penggunaan lahan yang terjadi baik yang beralih fungsi dan tidak beralih fungsi. Alih fungsi lahan terbesar terjadi di kecamatan gunungsitoli dengan persentase 25,38\% dari total luas perubahan di seluruh kecamatan kota gunungsitoli, dan persentase alih fungsi lahan yang terjadi terkecil di kecamatan gunungsitoli barat yang pada kenyataatanya kecamatan ini memiliki topografi landai dan bergelombang.

Gambar 2 memperlihatkan peta analisis perubahan lahan. Peta ini memberikan informasi bahwa Kawasan yang mengalami perubahan lahan terbesar terjadi di kecamatan Gunungsitoli. 
Tabel 3. Perubahan lahan terbangun dan tidak terbangun

\begin{tabular}{llccc}
\hline \multirow{2}{*}{ No } & \multicolumn{1}{c}{ Kecamatan } & \multicolumn{2}{c}{ Luas (Ha) } & \\
\cline { 3 - 4 } & & Beralih Fungsi & $\begin{array}{c}\text { Tidak Beralih } \\
\text { Fungsi }\end{array}$ & Jumlah Total \\
\hline 1. & Kec. Gunungsitoli & 352,51 & $4.134,44$ & $4.486,95$ \\
2. & Kec. Gunungsitoli Alo'oa & 196,19 & $3.913,19$ & $4.109,38$ \\
3. & Kec. Gunungsitoli Barat & 62,97 & $2.913,99$ & $2.976,96$ \\
4. & Kec. Gunungsitoli Idanoi & 184,81 & $5.516,88$ & $5.701,69$ \\
5. & Kec. Gunungsitoli Selatan & 125,03 & $4.315,31$ & $4.440,34$ \\
6. & Kec. Gunungsitoli Utara & 467,33 & $5.482,81$ & $5.950,14$ \\
\hline & $\quad$ Jumlah Total & $1.388,84$ & $26.276,62$ & $27.665,46$ \\
\hline
\end{tabular}

Sumber : Hasil analisis tahun 2019

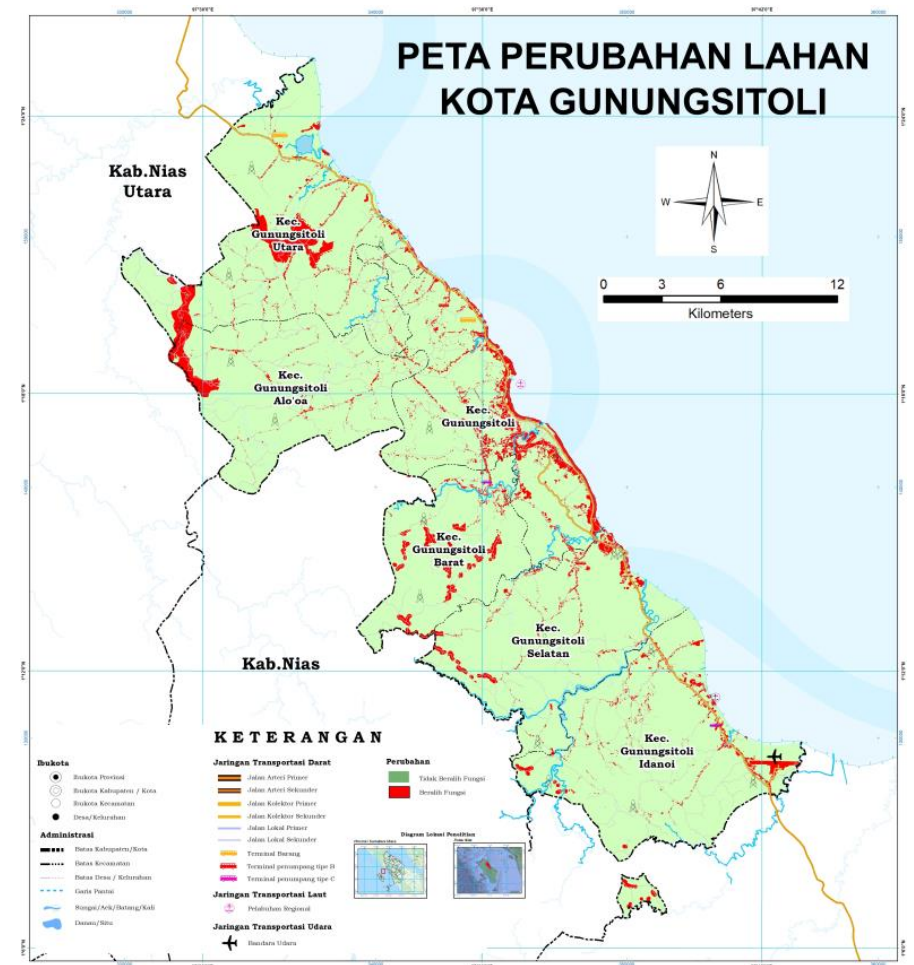

Gambar 2. Peta Perubahan Penggunaan Lahan Kawasan Rawan Bencana Tsunami di Kota Gunungsitoli Sumber: Olah data (2019)

Tabel 4 memaparkan tentang perubahan penggunaan lahan Kota Gunung Sitoli tahun 2010 dengan tahun 2019. Pada tabel matriks persandingan sangat terlihat jelas bahawa beberapa fungsi lahan pada tahun 2010 sudah mengalami alih fungsi misalnya saja pada tahun 2010 hutan lindung beralih fungsi sebanyak 3,16 hektar beberapa perubahan lahan lainnya pada dilihat pada tabel tersebut. 
Tabel 4. Perubahan penggunaan lahan tahun 2010 dan tahun 2019

\begin{tabular}{|c|c|c|c|c|c|c|c|c|c|c|}
\hline \multirow[b]{2}{*}{ No } & \multirow[b]{2}{*}{ Guna Lahan Tahun 2019} & \multicolumn{8}{|c|}{ Guna Lahan Tahun 2010 (Ha) } & \multirow[b]{2}{*}{$\begin{array}{c}\text { Jumlah } \\
\text { Total }\end{array}$} \\
\hline & & $\begin{array}{l}\text { Hutan } \\
\text { Alam }\end{array}$ & $\begin{array}{l}\text { Hutan } \\
\text { Lahan } \\
\text { Kering }\end{array}$ & $\begin{array}{c}\text { Kebun } \\
\text { Campuran }\end{array}$ & Mangrove & Perkebunan & Permukiman & $\begin{array}{l}\text { Semak/ } \\
\text { Belukar }\end{array}$ & $\begin{array}{l}\text { Tegalan/ } \\
\text { Ladang }\end{array}$ & \\
\hline 1. & Bandar Udara Binaka & & & & & & & & 43,93 & 43,93 \\
\hline 2. & Hutan Lindung & 287,16 & 395,49 & 175,38 & & & 3,16 & $1.614,76$ & 366,85 & $2.842,80$ \\
\hline 3 & Hutan Mangrove & & & & 79,88 & & & & 17,72 & 101,88 \\
\hline 4. & Hutan Produksi Konversi & & & 57,42 & & & 0,98 & 5,83 & & 64,23 \\
\hline 5. & Ladang/Tagelan & & & 8,35 & & 0,96 & & 90,11 & 20,19 & 119,61 \\
\hline 6. & Lahan Kosong & & & 1,43 & & & 0,24 & 7,06 & 0,50 & 9,23 \\
\hline 7. & Lahan Terbuka & & & 21,52 & & & 14,64 & 344,79 & 91,34 & 476,61 \\
\hline 8. & Pantai & & & & 0,85 & & 0,67 & 2,98 & 1,04 & 5,54 \\
\hline 9. & Pelabuhan Laut & & & & & & 1,82 & & & 1,82 \\
\hline 10. & Perkebunan Campuran & & & & & & & 46,06 & 62,57 & 108,63 \\
\hline 11. & Permukiman & 6,87 & 9,46 & 50,73 & 6,59 & 37,08 & 244,46 & 631,65 & 130,90 & $1.117,81$ \\
\hline 12. & Pertanian Lahan Basah & & & 0,43 & 3,06 & & & 33,70 & 66,83 & 104,02 \\
\hline 13. & Pertanian Lahan Kering & 197,09 & 985,22 & $2.088,55$ & 35,67 & 328,09 & 298,04 & $13,844,40$ & $4,036,50$ & $21.830,46$ \\
\hline 14. & Sawah & & & 72,85 & & 1,11 & 153,75 & 249,02 & 196,22 & 673,23 \\
\hline & Jumlah Total & 491,12 & $1.390,17$ & $2.476,66$ & 126,05 & 367,24 & 717,76 & $16.870,36$ & $5.034,59$ & $27.499,8$ \\
\hline
\end{tabular}




\section{Analisis Daerah Rawan Bencana Tsunami}

Analisis daerah rawan bencana tsunami dalam pengembangan dan pemanfaatan lahan perumahan dan permukiman Kota Gunungsitoli, dilakukan dengan cara atau metode tumpang susun dan permodelan data. Metode tumpang susun dilaksanakan dengan menggabungkan data grafis parameter-parameter yang mempengaruhi tsunami untuk menghasilkan kawasan daerah rawan bencana tsunami. Permodelan data dilakukan dengan tujuan sebagai perencanaan dan analisis data, seluruh bobot dan skor pada keseluruhan kriteria yang sudah ditetapkan akan diproses dengan menggunakan software ArcGIS 10.5 dengan tujuan untuk menghasilkan klasifikasi daerah rawan bencana tsunami berdasarkan tingkat kerawanan bencana tsunami. Berdasarkan bobot yang diberikan untuk setiap parameter maka dapat diperoleh skor tertinggi dan terendah. Jumlah total skor tertinggi dikurangi jumlah total skor terendah dibagi dengan jumlah kelas kerawanan maka akan diperoleh nilai rentangan skor (Rs) untuk kelas kerawanan dan dapat ditulis sebagai berikut:

$$
R s=\frac{\sum(B i x S i) M a x-\sum(B i x S i) M i n}{5}
$$

Dimana:

Rs $=$ Rentangan skor

$\mathrm{Bi}=$ Bobot pada tiap kriteria

$\mathrm{Si}=$ Skor pada tiap kriteria

Dari perhitungan rumus nilai kerentanan (Rs), didapatkan hasil rentangan dengan skor 60 dimana jumlah total skor minimum adalah 30 dan jumlah total skor maksimum sebesar 273. Penentuan masingmasing kelas kerawan dilakukan berdasarkan skor yang ada. Untuk lebih jelasnya mengenai klasifikasi tingkat kerawanan tsunami dapat dilihat pada Tabel 5.

Tabel 5. Klasifikasi tingkat kerawanan tsunami

\begin{tabular}{lll}
\hline No & Klasifikasi & Skor \\
\hline 1. & Sangat Rawan & $30-90$ \\
2. & Rawan & $91-151$ \\
3. & Agak Rawan & $152-212$ \\
4. & Aman & $213-273$ \\
5. & Sangat Aman & $>273$ \\
\hline
\end{tabular}

Sumber: Hasil analisis tahun 2019

Tabel 5. Memaparkan tentang kelasifikasi tingkat kerawan bencana tsunami, sebaran zona tersebut adalah untuk tingkat klasifikasi sangat rawan memiliki persentase 3\% atau dengan luas kawasan 834.68 hektar, kelas rawan seluas 2.965,68 hektar atau 10,7\%, untuk kelas agak rawan seluas 3.810,71 hektar atau dengan persentase $13,7 \%$, kelas aman seluas $7.832,9$ hektar atau $28.1 \%$ dan untuk klasifikasi sangat aman seluas 12.384,9 hektar atau persentase 44,5\% dari luas wilayah zona bencana di Kota Gunungsitoli. Pada kelasifikasi sangat aman memiliki persentase yang cukup tinggi, ini disebabkan oleh sebaran zona tersebut berada pada daerah dengan topografi tinggi dan berbukit sehingga kerentanan bencana tsunaminya sangat minim.

Gambar 3 Mengambarkan distribusi tingkat kerawan bencana pada setiap kecamatan di Kota Gunung Sitoli, pada grafik tersebut memperlihatkan bahwa kecamatan Gunung Sitoli merupakan salah satu kecamatan yang memiliki nilai kerentanan paling luas dengan besaran 3.449 Hektar. Selanjutnya di ikuti oleh Kecamatan Gunung Sitoli Idanoi, Kecamatan Gunung Sitoli Selatan dan Kecamatan Gunung Sitoli Utara. 


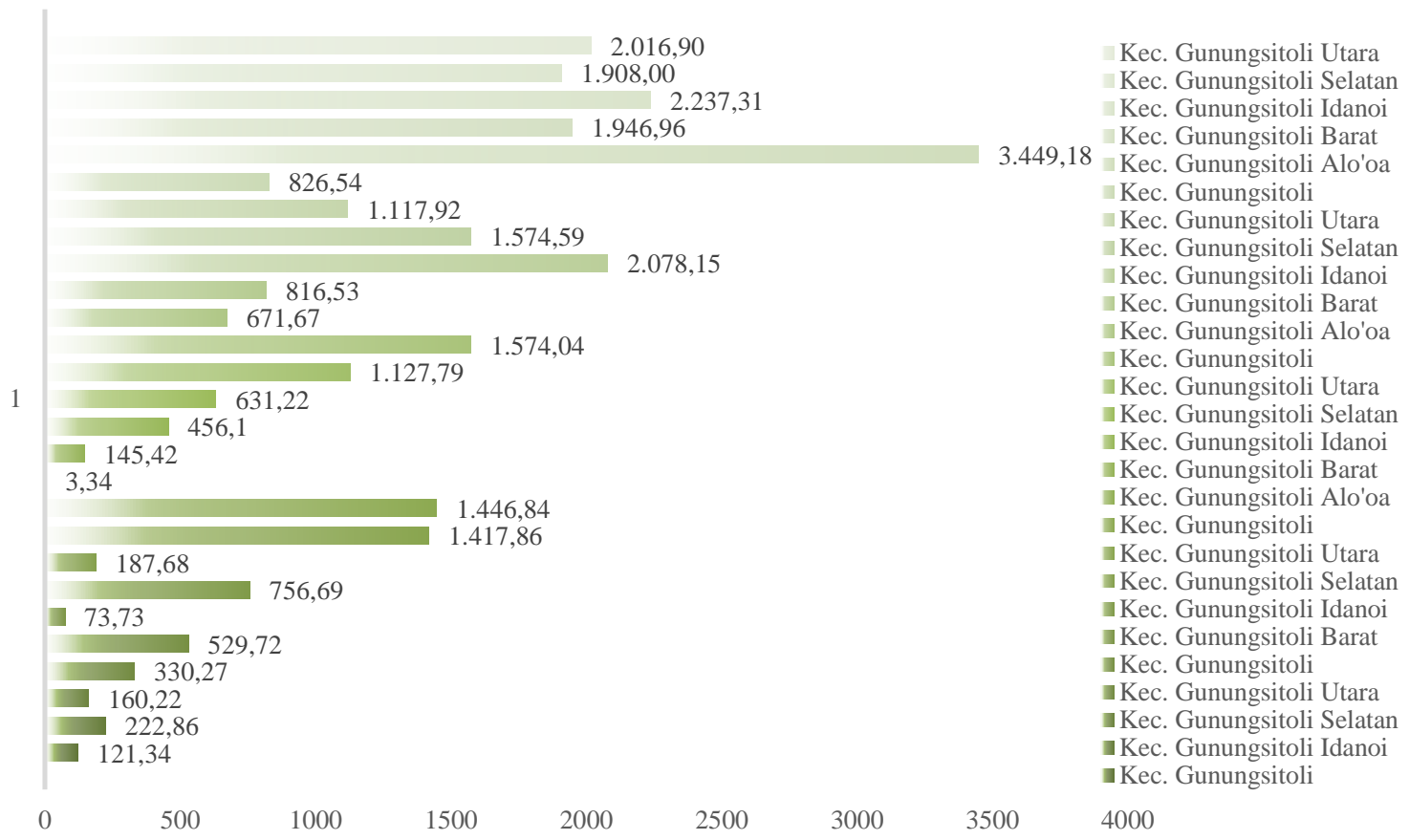

Gambar 3. Grafik distribusi tingkat kerawanan tsunami berdasarkan kecamatan Sumber: Olah data (2019)

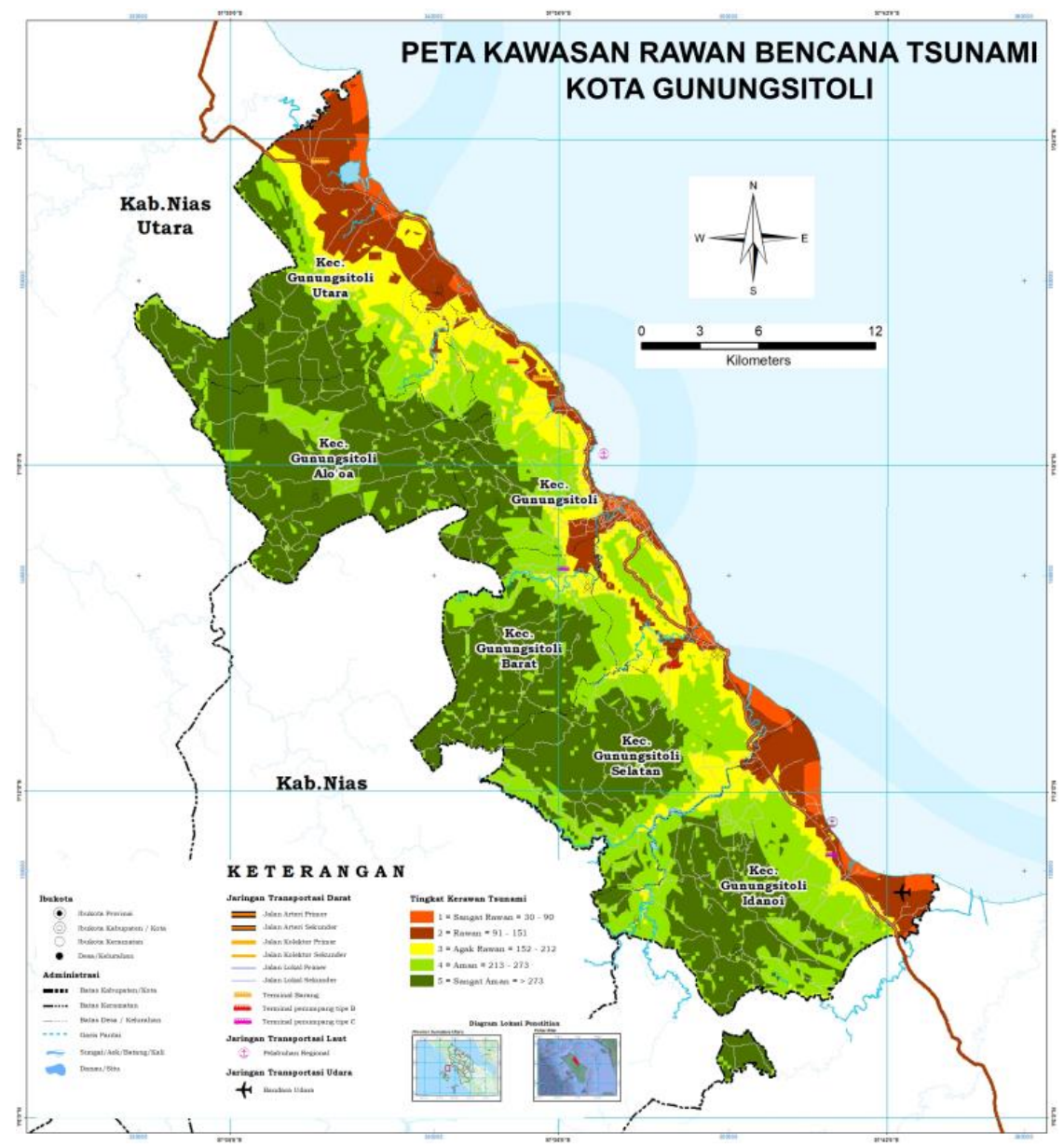

Gambar 4. Peta kawasan rawan bencana tsunami di Kota Gunungsitoli Sumber: Olah data (2019) 
Gambar 4 memperlihatkan peta analisis sebaran rawan bencana tsunami. Peta ini memberikan informasi bahwa kawasan yang berdekatan dengan pinggir pantai adalah awasan yang paling rawan terkena dampak bencana tsunami.

Tabel 6. Distribusi bangunan terhadap tingkat kerawanan bencana

\begin{tabular}{llcccccc}
\hline \multirow{2}{*}{ No } & Kecamatan & \multicolumn{5}{c}{ Jumlah Bangunan (Unit) } \\
\cline { 3 - 6 } & & $\begin{array}{c}\text { Sangat } \\
\text { Aman }\end{array}$ & Aman & $\begin{array}{c}\text { Agak } \\
\text { Rawan }\end{array}$ & Rawan & $\begin{array}{c}\text { Sangat } \\
\text { Rawan }\end{array}$ & $\begin{array}{c}\text { Jumlah } \\
\text { Total }\end{array}$ \\
\hline 1. & Kec. Gunungsitoli & 544 & 1.737 & 7.087 & 7.469 & 3.603 & 20.440 \\
2. & Kec. Gunungsitoli Alo'oa & 890 & 390 & 0 & 0 & 0 & 1.280 \\
3. & Kec. Gunungsitoli Barat & 991 & 893 & 908 & 15 & 0 & 2.807 \\
4. & Kec. Gunungsitoli Idanoi & 3.144 & 2.596 & 1.919 & 2.824 & 410 & 10.893 \\
5. & Kec. Gunungsitoli Selatan & 2.176 & 1.448 & 1.537 & 1.008 & 656 & 6.825 \\
6. & Kec. Gunungsitoli Utara & 643 & 663 & 1.087 & 1.396 & 961 & 4.750 \\
\hline & Jumlah Total & 8.388 & 7.727 & 12.538 & 12.712 & 5.630 & 46.995 \\
\hline
\end{tabular}

Sumber: Hasil analisis tahun 2019
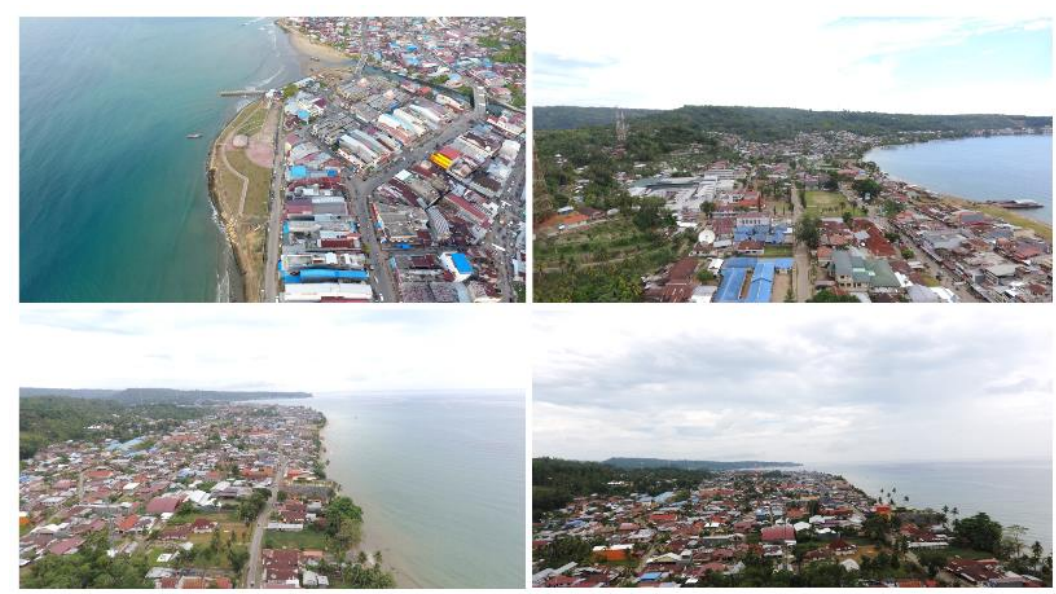

Gambar 5. Kondisi bangunan yang berada pada zona bencana Sumber: Hasil survei tahun 2019

Tabel 6 menjelaskan tentang hasil analisis dan kelasifikasi kawasan rawan bencana tsunami terhadap pengembangan kawasan perumahan dan permukiman di Kota Gunung Sitoli, memberikan gambaran terhadap pola dan struktur dari arah perkembangan pendirian bangunan sampai pada tahun 2019. Dengan dengan menggunakan method overlay, serta persandingan antara kawasan rawan bencana tsunami dengan bangunan-bangunan yang berdiri di Kota Gunungsitoli memberikan gambaran dengan jelas bahwa bangunan yang berdiri pada kawasan yang sangat rawan akan bencana tsunami sebanyak 5.630 unit dari 46.995 unit bangunan di Kota Gunungsitoli.

Gambar 5 memperlihatkan beberapa foto dari ketinggian. Foto-foto ini memaparkan terkait visual kondisi bangunan di Kota Gunung Sitoli yang berpada pada daerah rawan bencana tsunami, dimana bangunan-bangunan tersebut berapada tepat pada pinggir pantai kota.

\section{Kesimpulan dan Saran Kesimpulan}

1. Kependudukan

Hasil proyeksi penduduk yang sudah dilakukan dengan menggunakan alat analisis exponensial memperlihatkan bahwa pertumbuhan penduduk secara holistik di Kota Gunungsitoli dalam kurun waktu 20 tahun kedepan, kondisi tersebut secara tidak langsung mempengaruhi perkembangan pemanfaatan ruang untuk kebutuhan tempat tinggal dan kegiatan lainnya oleh masyarakat.

2. Perubahan Penggunaan Lahan

Penggunaan lahan di Kota Gunungsitoli mengalami perubahan dan alihfungsi lahan sebesar 1.388,84 hektar atau dengan persentase 5,02\% dari total luas Kota Gunungsitoli, yang artinya kondisi tersebut 
menggambarkan akan perkembangan dan pertumbuhan pembangunan yang terjadi di Kota Gunungsitoli.

3. Kawasan Rawan Bencana Tsunami

Dari hasil analisis spasial yang telah dilakukan oleh peneliti yang berbasis pada penggunaan Sistem Informasi Geografis (SIG), memperoleh kesimpulan tentang klasifikasi tingkat kerawanan bencana tsunami di Kota Gunungsitoli yaitu antara lain:

a) Klasifikasi sangat aman memiliki luas 12.384 hektar atau dengan persentase $44,50 \%$ dari luas wilayah Kota Gunungsitoli

b) Klasifikasi aman memiliki luas 7.832 hektar atau dengan persentase $28 \%$ dari luas wilayah Kota Gunungsitoli

c) Klasifikasi agak rawan memiliki luas 3.810 hektar atau dengan persentase $13,69 \%$ dari luas wilayah Kota Gunungsitoli

d) Klasifikasi rawan memiliki luas 2.965 hektar atau dengan persentase 10,6\% dari luas wilayah Kota Gunungsitoli

e) Klasifikasi sangat rawan memiliki luas 834,69 hektar atau dengan persentase 2,9\% dari luas wilayah Kota Gunungsitoli

4. Persandingan Kawasan Rawan Bencana Tsunami terhadap Rencana Tata Ruang Wilayah (RTRW)

Hasil persandingan Rencana Pola Ruang RTRW Kota Gunungsitoli dengan kawasan rawan bencana tsunami menjelaskan bahwa pengembangan kawasan permukiman yang ditetapkan dalam RTRW Kota Gunungsitoli berada pada daerah kawasan rawan bencana tsunami dengan tingkat kerawanan sangat rawan, dengan luas pengembangan permukiman 126,11 hektar.

\section{Saran}

1. RTRW Kota Gunungsitoli sebaiknya dalam pengembangan dan arahan pemanfaatan lahan kota perlu memperhatikan aspek kerawanan bencana tsunami dalam perwujudan peruntukan permukiman dan perumahan sebagai upaya dalam melaksanakan dan mengakomodir mitigasi bencana. Ini dikarenakan secara geografis Kota Gunungsitoli merupakan bagian dari wilayah Megatrusht khususnya gempa bumi.

2. Pengendalian pemanfaatan ruang wilayah kota semestinya betul-betul menjadi perhatian khusus pemerintah Kota Gunungsitoli didalam mengatur dan mengawasi pembangunan yang tidak sesuai dengan peruntukkan yang telah ditetapkan. Dengan begitu alihfungsi lahan dapat terkendali sehingga masyarakat dan investor taat akan pembangunan serta pemanfaatan ruang yang berkelanjutan.

\section{Daftar Pustaka}

[1] P. K. Gunungsitoli, Peraturan Daerah Kota Gunungsitoli tentang Rencana Tata Ruang Wilayah Kota Gunungsitoli no 12-2012. 2012.

[2] P. R. Indonesia, Undang-Undang Republik Indonesia Nomor 26 Tahun 2007 Tentang Penataan Ruang. 2007.

[3] B. P. Statistik, "Kota Gunungsitoli Dalam Angka,” Kota Gunungsitoli, 2019.

[4] Sugiyono, "Metode Penelitian Bisnis (Pendekatan Kuantitatif, kualitatif, dan R\&D)," Alfabeta. 2017.

[5] I. Ediningtias, "Laporan Pengantar Ilmu Kependudukan," 2017.

[6] R. A. Pratomo and I. Rudiarto, "Permodelan Tsunami dan Implikasinya Terhadap Mitigasi Bencana di Kota Palu," J. Pembang. Wil. KOTA, 2013.

[7] V. N. Chudori, "Relevansi Isi Kurikulum Keahlian Teknik Konstruksi Batu dan Beton di SMKN 5 Bandung Dengan Kebutuhan Industri," Universitas Pendidikan Indonesia, 2012.

[8] D. Harnovinsah, "Metodologi Penelitian." [Online]. Available: https://mercubuana.ac.id/files/MetodeLogiPenelitian/Met Pen UMB 3-ok.pdf. [Accessed: 09-Dec2019].

[9] R. Hidayah, "Studi Evaluatif Sebagai Upaya Optimalisasi Modul Mata Kuliah Fungsi Teknis Reserse Kriminal Untuk Taruna Program Sarjana Strata Satu (S-1) Terapan Kepolisian Di Akademi Kepolisian," Universitas Negeri Semarang, 2018.

[10] D. Lestari, "Penerapan Metode Eksponensial pada Proyeksi Laju Pertumbuhan Penduduk di Sumatera Utara Tahun 2019," 2018.

[11] M. Ilyas, K. Munibah, and O. Rusdiana, "Analisis Spasial Perubahan Penggunaan Lahan Dalam Kaitannya Dengan Penataan Zonasi Kawasan Taman Nasional Gunung Halimun-Salak," Maj. Ilm. Globë, vol. 16, pp. 33-34, 2014.

[12] E. Prahasta, Konsep-konsep dasar sistem informasi geografis. Bandung: Penerbit Informatika, 
2001.

[13] A. S. Dhuha Ginanjar Bayuaji, Arief Laila Nugraha, "Analisis Penentuan Zonasi Risiko Bencana Tanah Longsor Berbasis Sistem Informasi Geografis (Studi Kasus: Kabupaten Banjarnegara)," J. Geod. Undip, vol. 5, 2016.

[14] H. Voogd, "Multicriteria evaluation with mixed qualitative and quantitative data," Environ. Plan. B Plan. Des., 1982.

[15] I. Kaliszewski and D. Podkopaev, "Simple additive weighting - A metamodel for multiple criteria decision analysis methods," Expert Syst. Appl., 2016.

[16] P. Subardjo and R. Ario, "Uji Kerawanan Terhadap Tsunami Dengan Sistem Informasi Geografis (SIG) Di Pesisir Kecamatan Kretek, Kabupaten Bantul, Yogyakarta,” J. Kelaut. Trop., vol. 18, pp. 82-97, 2015.

[17] MPBI_UNESCO, "Kajian Kesiapsiagaan Masyarakat dalam mengantisipasi bencana gempa Bumi dan tsunami di Nias Selatan," J. Chem. Inf. Model., 2013. 